\title{
Daun Waru Sebagai Bahan Dasar Pembuatan Detergen Ramah Lingkungan
}

\author{
Tien Faizah Azfi \\ SMKS Muhammadiyah Pangkalan Bun, Jalan Jenderal Sudirman No.13A \\ Pangkalan Bun Kalimantan Tengah 74111, Indonesia \\ tienfaizahazfi@yahoo.co.id
}

\begin{abstract}
Abstrak. Pada saat ini, tersedia berbagai nama dari detergen yang digunakan masyarakat sebagai bahan pembantu dalam mencuci pakaian tanpa memperdulikan akibat dari penggunaan, baik terhadap lingkungan maupun pengguna detergen itu sendiri. Daun waru (Hibiscus Tiliance L) yang memiliki kandungan busa (saponin) yang berfungsi sebagai bahan pencuci yang memiliki sifat seperti sabun dan bertindak sebagai surfaktan sebagai bahan dasar dari pembuatan detergen ramah lingkungan. Penelitian ini menggunakan metode kuantitatf dengan populasi dan sampel daun waru. Sampel penelitian diambil secara acak atau random pada populasi yang telah ditetapkan. Teknik pengambilan data melalui metode eksperimen. Variabel penelitian terdiri atas variable bebas $(\mathrm{X})$ yaitu daun waru dan variable terikat $(\mathrm{Y})$ yaitu detergen ramah lingkungan. Hasil eksperimen membuktikan bahwa daun waru dapat dijadikan sebagai bahan dasar dari pembuatan detergen ramah lingkungan sebagai alternatif potensial untuk dikembangkan yang aman dan ramah lingkungan serta sebagai upaya mengurangi daya rusak air akibat penggunaan detergen sintetik yang dapat merusak kualitas air dan lingkungan. Diperlukan penelitian lebih lanjut untuk menyempurnakan hasil eksperimen ini.
\end{abstract}

Kata Kunci: daun waru, deterjen, saponin.

\section{PENDAHULUAN}

Pada perkembangan zaman ini, banyak sekali aktivitas atau kegiatan yang dilakukan manusia yang dapat menyebabkan kerusakan lingkungan. Salah satu aktivitas tersebut adalah penggunaan berbagai produk instant oleh masyarakat yang ternyata mengandung bahan-bahan kimia tidak ramah lingkungan. Akibatnya, lingkungan alam menjadi tercemar serta keseimbangan ekosistem menjadi terganggu. Contoh produk instant yang sering digunakan oleh masyarakat adalah detergen pencuci pakaian.

Deterjen merupakan produk formulasi campuran beberapa bahan kimia, yang bertujuan untuk meningkatkan kemampuan membersihkan.

Penggunaan deterjen sintesik sebagai bahan pembersih dalam kehidupan seharihari semakin meningkat sehingga dapat mengakibatkan kerusakan air dan lingkungan sekitar karena deterjen mengandung beberapa bahan berbahaya bagi lingkungan.

"Daun waru merupakan salah satu daun yang memiliki kandung zat aktif tinggi berupa saponin, flavonoida, fenol dan tanin" (Pujo Siswoyo, 2009).

"Saponinadalah senyawa dalam bentuk glikosida yang tersebar luas pada tumbuhan tingkat tinggi.Saponinmembentuk larutan koloidal dalam air dan membentuk busa yang mantap jika dikocok dan tidak hilang dengan penambahan asam" (Harbrone,1996). 
Oleh karena itu penulis ingin membuat deterjen ramah lingkungan dengan berbahan dasar daun waru sebagai alternativ bahan yang aman dan ramah lingkungan.

\section{METODE PENELITIAN}

Metode Penelitian yang digunakan adalah metode penelitian eksperimen (metode kuantitatif).

Variabel dalam penelitian ini adalah sebagai berikut :

a.Variabel Independen $(X)$, yaitu daun waru.

b.Variabel Dependen (Y), yaitu detergen ramah lingkungan.

Populasi dan sampel diambil dari beberapa daun waru acak dari pohon yang berbeda.

Dalam penelitian ini, sampel yang sah yang kita pilih yaitu percobaan atau eksperimen yang dilakukan oleh 15-30 lembar daun waru di Pangkalan Bun.

\section{HASIL PENELITIAN DAN PEMBAHASAN}

Dari hasil eksperimen, dapat dibuktikan bahwa daun waru dapat dijadikan sebagai bahan dasar pembuatan detergen ramah lingkungan. Detergen inisebagai alternatif potensial yang dikembangkan untuk mengurangi daya rusak air akibat penggunaan detergen sintetik.

Dari tiga kali percobaan, dihasilkan kualitas detergen yang berbeda.

1. Percobaan pertama menggunakan 15 helai daun waru dan menghasilkan sekitar $300 \mathrm{ml}$ detergen cair, tetapi setelah diuji coba hasilnya kurang efektif dalam membersihkan noda.

2. Percobaan kedua menggunakan 30 helai daun waru dan menghasilkan sekitar $500 \mathrm{ml}$ detergen cair, dan setelah diuji coba hasilnya sangat baik dalam menghilakan noda yang menempel pada pakaian, tetapi hasil dari cucian berbau seperti daun waru.

3. Percobaan ketiga menggunakan 30 helai daun waru dengan tambahan bibit parfume yang tidak berbahaya bagi lingkungan dan menghasilkan sekitar 500 $\mathrm{ml}$ detergen cair, dan setelah diuji coba hasilnya sangat baik dalam menghilakan noda yang menempel pada pakaian serta pakaian dapat bersih dan berbau harum.

Daun waru memiliki kandungan busa (saponin) yang berfungsi sebagai bahan pencuci yang memiliki sifat seperti sabun dan bertindak sebagai surfaktan. Tingkat kebersihan mencuci dengan daun waru sama dengan detergen sintetik, bahkan daun waru tidak melunturkan pakaian sehingga mampu mempertahankan kualitas kain seperti sebelumnya.

\section{SIMPULAN}

Penggunaan detergen ramah lingkungan berbahan dasar daun waru ini lebih ekologis dan ekonomis jika dibandingkan dengan detergen sintetik. Karena detergen ramah lingkungan ini mengandung Saponin yang dapat meminimalisir terjadinya pencemaran lingkungan. Kandungan kimia yang terdapat pada daun waru lebih ramah lingkungan karena mudah mengalami biodegradibilitas dan juga diharapkan dapat meningkatkan efektivitas daya pembersih detergen yaitu dengan mendegradasi kotoran.Hal ini memberikan potensi bahan - bahan alami 
ini untuk dikembangkan menjadi bahan detergen. Pemanfaatan bahan kimia yang dapat merusak alam dalam jangka panjang akan mampu diatasi dengan penggunaan detergen dari bahan alami seperti daun waru ini.

\section{DAFTAR PUSTAKA}

Harbrone.J.B,. 1987.Metode Fitokimia : Penuntun Cara Moderen Menaganalisis Tumbuhan, Terbitan Kedua,ITB : Bandung Kim Nio, Ocy.,1989. Zat-zat toksik yang secara alamiah ada pada tumbuhan nabati. Cermin Dunia Kedokteran:Bandung.

Sastrawijaya, A. T., 1991, "Pencemaran Lingkungan", Rineka Cipta, Jakarta Siswoyo, Pujo. 2009. Tumbuhan Berkhasiat Obat.Yogyakarta: Absolut.

Sugiono. 2010. Penelitian Kuantitatif Kualitatif dan R\&D. Bandung: Alfabeta. Suharsimi, Arikunto. 2006. Prosedur Penelitian (Suatu Pendekatan Praktik). Jakarta: Rineka Cipta. 